\title{
Identification and quantitative analyses of microRNAs located in the distal axons of sympathetic neurons
}

\author{
ORLANGIE NATERA-NARANJO, ${ }^{1}$ ARMAZ ASCHRAFI, ${ }^{1}$ ANTHONY E. GIOIO, and BARRY B. KAPLAN \\ Laboratory of Molecular Biology, National Institute of Mental Health, National Institutes of Health, Bethesda, Maryland 20892-1381, USA
}

\begin{abstract}
microRNAs (miRNAs) constitute a novel class of small, noncoding RNAs that act as negative post-transcriptional regulators of gene expression. Although the nervous system is a prominent site of miRNA expression, little is known about the spatial expression profiles of miRNAs in neurons. Here, we employed compartmentalized Campenot cell culture chambers to obtain a pure axonal RNA fraction of superior cervical ganglia (SCG) neurons, and determined the miRNA expression levels in these subcellular structural domains by microarray analysis and by real-time reverse-transcription polymerase chain reaction. The data revealed stable expression of a number of mature miRNAs that were enriched in the axons and presynaptic nerve terminals. Among the 130 miRNAs identified in the axon, miR-15b, miR-16, miR-204, and miR-221 were found to be highly abundant in distal axons as compared with the cell bodies of primary sympathetic neurons. Moreover, a number of miRNAs encoded by a common primary transcript (pri-miRNA) were differentially expressed in the distal axons, suggesting that there is a differential subcellular transport of miRNAs derived from the same coding region of the genome. Taken together, the data provide an important resource for future studies on the regulation of axonal protein synthesis and the role played by miRNAs in the maintenance of axonal structure and function as well as neuronal growth and development.
\end{abstract}

Keywords: superior cervical ganglion; primary neurons; microRNA; microarray profiling; real-time PCR; target mRNAs

\section{INTRODUCTION}

Subcellular mRNA localization comprises a fundamental mechanism for regulated gene expression in developing and adult brain. The resulting temporal and spatial patterns of local protein synthesis is required for a number of important neuronal processes, such as differentiation and maturation, axon guidance, synapse formation, and cognitive brain functions (Costa-Mattioli et al. 2009). Previous studies identified that local translation is under tight control via a number of different mechanisms, such as control of mRNA stability (Smart et al. 2007), translation initiation (Klann et al. 2004), and elongation (Huang et al. 2005) and by the recently discovered noncoding miRNAs (for review, see Schratt 2009a). At present, there is little knowledge of the intricate nature and role played by miRNAs in the axons and synaptic terminals of neurons. The regulation of

\footnotetext{
${ }^{1}$ These authors contributed equally to this work.

Reprint requests to: Barry B. Kaplan, Laboratory of Molecular Biology, National Institute of Mental Health, National Institutes of Health, 10 Center Drive, Room 4A15, Bethesda, MD 20892-1381, USA; e-mail: kaplanb@mail.nih.gov; fax: (301) 594-3189.

Article published online ahead of print. Article and publication date are at http://www.rnajournal.org/cgi/doi/10.1261/rna.1833310.
}

gene expression by miRNAs represents a distinct mechanism of translation regulation. miRNAs are single-stranded RNA moieties of about 21-23 nucleotides (nt) in length. They are highly conserved and involved in a subset of biological processes in which they have been shown to be implicated in developmental timing, cell proliferation, apoptosis, metabolism, cell differentiation, and morphogenesis (Ambros and Lee 2004; Niwa and Slack 2007). Several recent reviews provide detailed descriptions of miRNA biogenesis and mode of action (Kim 2005; Filipowicz et al. 2008). Remarkably, it has been shown that these small molecules coordinately regulate multiple genes coding for proteins with related cellular functions (van Rooij and Olson 2007), and their presence in the dendrites of neurons has been previously reported (Kye et al. 2007; Lugli et al. 2008; Siegel et al. 2009).

The functions of individual miRNAs in neurons are just beginning to emerge, and multiple lines of evidence point to the widespread involvement of miRNAs in various neurological diseases (for review, see Bassell and Warren 2008; Hunsberger et al. 2009). In addition, recent studies have elucidated several roles for neural miRNAs at various stages of synaptic development, including dendritogenesis, synapse formation, and synapse maturation. Furthermore, some of 
these studies have shown that miRNAs regulate mRNA translation locally in the synaptodendritic compartment (for review, see Schratt 2009b). In recent studies, we delineated a novel molecular mechanism by which the brainspecific miR-338 participated in the regulation of axonal growth and function by locally modulating the levels of a nuclear-encoded mitochondrial protein. This finding points to a novel mechanism for a soma-independent regulation of protein synthesis in distal axons through neuronal miRNAs (Aschrafi et al. 2008).

In the present study, we employed a compartmentalized cell culture system to obtain a pure axonal RNA fraction of superior cervical ganglia (SCG) neurons, and present the results of a microarray analysis that led to the identification of a large heterogeneous population of axonal miRNAs. By combining microarray expression profiling with miRNAspecific real-time reverse-transcription polymerase chain reaction (RT-PCR), we provide, for the first time, a comprehensive list of miRNAs residing within the axonal domain. These data provide a base for future studies of individual miRNAs, their target genes, and the role played by the miRNAs in the regulation of local protein synthesis.

\section{RESULTS AND DISCUSSION}

Although we routinely monitor the side compartments of the Campenot cell culture chambers for the presence of neuronal cell soma and non-neuronal cells using light microscopy, trace cellular contamination of the axonal RNA preparation might still be detectable at the level of resolution afforded by microarray analysis or real-time PCR methodology. To address this issue, the purity of the RNA samples prepared from the distal axons was assessed by real-time PCR using gene-specific primer sets for mRNAs present in neuronal cell soma and glia. As shown in Figure 1A, amplicons for munc18, rim, and synapsin 3, mRNAs encoding proteins involved in synaptic vesicle function,
A

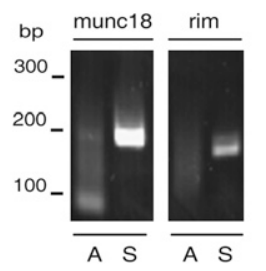

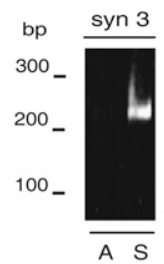

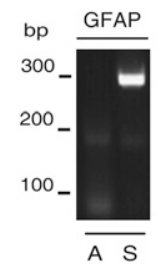

B

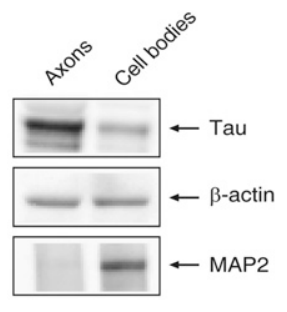

FIGURE 1. RNA prepared from the distal axons of SCG neurons is free of neuronal and glial contamination. (A) RT-PCR analysis was conducted on RNA obtained from the lateral and central compartments of the Campenot cell culture chambers using gene-specific primer sets for synaptic vesicle proteins, munc18, rim, synapsin 3 (syn 3), and glial fibrillary acidic protein (GFAP). PCR products were fractionated on 2.5\% agarose gels and amplicons visualized by ethidium bromide staining. (A) Axon; (S) soma; (bp) base pairs. (B) Protein lysates obtained from the lateral and central compartments of the Campenot chambers were analyzed by Western blot using antibodies against Tau and MAP2. Levels of $\beta$-actin immunoreactivity served as an internal control. were readily visualized in RNA prepared from the neurons present in the central compartment, but were not observed in RNA obtained from distal axons. Identical results were obtained using gene-specific primers for glial fibrillary acidic protein (Fig. 1A, GFAP). These data support the contention that the RNA prepared from the side compartments is free of neuronal and glial contamination.

Results of Western blot analysis performed on protein lysates obtained from the side and central compartments of the Campenot chambers indicate that the distal axonal fraction is enriched for axonal proteins (Fig. 1B). For example, the abundance of Tau, an axonal marker protein, relative to $\beta$-actin, was greater in the distal axons as compared with the neuronal soma (relative ratio axon to soma 4:1). In contrast, distal axons were devoid of MAP2, whereas this dendritic biomarker was readily detected in protein samples obtained from the central compartment (Fig. 1B).

Previously, we identified an axonally localized miRNA that regulates the expression of cytochrome $c$ oxidase IV (COXIV), a key protein within the electron transfer chain in mitochondria, which participates in the control of ATP levels in the axons of sympathetic neurons ( $\mathrm{Li}$ et al. 2006; Aschrafi et al. 2008). We reasoned that miRNAs that are important for axonal function and development might be located in distal axons, where they could locally regulate the translation of relevant target mRNAs. To investigate the global expression of miRNAs in the axons of primary SCG neurons, we isolated total RNA from the distal axons of SCG neurons, and delineated the component miRNAs using a miRNA microarray kit with optimized probe sequences targeting all of the known mature rat miRNAs in the miRBase Sequence Database, Release 9.0. In addition, e analyzed total RNA from the central compartments of these cultures, which contained the parental cell bodies and imal axons of these neurons. Microarray expression profiling revealed that axons of rat sympathetic neurons contain a large, heterogeneous population of miRNAs (Supplemental Table S1): Several of these miRNAs are highly expressed in these neurons. A listing of miRNAs that are most abundant and/or enriched in the axon is provided in Table 1 . In addition, the microarray data demonstrated that miRNAs belonging to the same family could be readily differentiated by this experimental approach. For example, miR-125a and miR-125b differ only by three nucleotides, but yielded highly reliable and markedly different signal intensities of 41.2 ( \pm 5.2 SEM) and 322.5 ( \pm 43.8 SEM) relative fluorescence units (RFU), respectively.

To further assess the distribution of the miRNAs in the axons as compared with cell bodies, we calculated the ratios 
TABLE 1. List of select relatively abundant or enriched axonal miRNAs as assessed by microarray analysis ${ }^{\mathrm{a}}$

\begin{tabular}{lccc}
\hline $\begin{array}{l}\text { miRNA } \\
\text { name }\end{array}$ & $\begin{array}{c}\text { Axon } \\
\text { intensity }\end{array}$ & $\begin{array}{c}\text { Soma } \\
\text { intensity }\end{array}$ & $\begin{array}{c}\text { Ratio } \\
\text { of intensities } \\
\text { (axon/soma) }\end{array}$ \\
\hline rno-miR-125b & $322.50 \pm 43.75$ & $247.67 \pm 42.67$ & $1.35 \pm 0.15$ \\
rno-miR-382 & $132.33 \pm 9.83$ & $165.17 \pm 14.49$ & $0.85 \pm 0.12$ \\
rno-miR-23a & $126.17 \pm 11.70$ & $97.17 \pm 11.49$ & $1.33 \pm 0.12$ \\
rno-miR-23b & $125.67 \pm 3.91$ & $108.50 \pm 10.98$ & $1.16 \pm 0.12$ \\
rno-miR-24 & $83.50 \pm 9.30$ & $106.83 \pm 18.77$ & $0.84 \pm 0.11$ \\
rno-miR-329 & $43.00 \pm 4.57$ & $95.50 \pm 15.66$ & $0.48 \pm 0.04$ \\
rno-miR-26a & $41.67 \pm 2.63$ & $33.83 \pm 2.48$ & $1.24 \pm 0.06$ \\
rno-miR-221 & $41.17 \pm 4.50$ & $7.17 \pm 0.83$ & $5.83 \pm 0.49$ \\
rno-miR-16 & $34.33 \pm 1.86$ & $9.83 \pm 3.13$ & $3.69 \pm 0.35$ \\
rno-miR-185 & $33.67 \pm 0.67$ & $55.83 \pm 5.18$ & $0.62 \pm 0.05$ \\
rno-miR-103 & $32.50 \pm 2.14$ & $18.33 \pm 1.33$ & $1.81 \pm 0.15$ \\
rno-miR-127 & $31.33 \pm 3.17$ & $23.00 \pm 3.81$ & $1.44 \pm 0.15$ \\
rno-miR-320 & $31.17 \pm 2.02$ & $14.33 \pm 1.65$ & $2.29 \pm 0.24$ \\
rno-miR-541 & $27.67 \pm 1.99$ & $20.33 \pm 2.74$ & $1.49 \pm 0.21$ \\
\hline
\end{tabular}

Enriched miRNAs manifest axon/soma intensity ratios $>1.0$.

${ }^{a}$ Microarray data are shown as average of six replicates $( \pm$ SEM).

were higher than 36, and the corresponding standard deviations were high $(\geq 1)$. Additionally, melting curve analyses of the amplicons revealed a lack of fidelity of the signal. A rank ordering of the 15 most abundant miRNAs, as judged by qRT-PCR analysis ( $\mathrm{C}_{\mathrm{T}}$ values), is provided in Table 2 .

Following the establishment of the cutoff $C_{T}$ value, we calculated the relative expression (RQ) of the miRNAs in the axons compared with the soma using the comparative $\mathrm{C}_{\mathrm{T}}$ method (Schmittgen and Livak 2008). This method has been successfully employed in the quantitative analyses of miRNA expression by realtime PCR (Saba et al. 2008; Schmittgen et al. 2008; Aldrich et al. 2009; Hébert et al. 2009). Briefly, $\Delta C_{T}$ values for each miRNA were obtained after normalizing to U6 snRNA, a common normalizer for miRNA expression, and miR-103, which

of the axonal signal intensities compared with the signal intensities in the cell body for each miRNA. The distribution pattern for 60 miRNAs is shown in Figure 2A. The average ratio (axon/soma) obtained for the miRNAs by microarray profiling was 1.26 ( $\pm 0.08 \mathrm{SEM})$, suggesting that most miRNAs have similar relative abundances between the cell bodies and distal axons. However, a number of miRNAs were observed that were significantly enriched in the axons compared with the cell bodies, while others were enriched or present only in the cell bodies. For example, miR-204, miR-221, miR-15b, and miR-16 are characterized by the former pattern, while miR-297, miR-206, and miR124a are examples of the latter pattern. This finding confirmed previous studies reporting that miR-124a, a miRNA important for neuronal differentiation, is cell-body restricted, as assessed by microarray analysis, in situ hybridization (ISH), and RT-PCR (Kye et al. 2007; Siegel et al. 2009).

To validate the microarray analysis, we assessed the expression of 57 miRNAs by real-time quantitative RTPCR (qRT-PCR) using miRNA-specific primers. As selection criteria, we chose miRNAs found to be highly expressed by microarray, with axonal signal intensities that were three standard deviations above the background intensity, as well as some that were expressed at a lower level, with signal intensities that were one to two standard deviations above background. In addition, 17 miRNAs with microarray intensities less than one standard deviation above background level were assayed by qPCR to establish a cutoff $\mathrm{C}_{\mathrm{T}}$ value. Previously, it was shown that mature miRNAs present in low copy number have $\mathrm{C}_{\mathrm{T}}$ values higher than 35 (Schmittgen et al. 2008). Consistent with this finding, the $\mathrm{C}_{\mathrm{T}}$ values obtained for 16 of these miRNAs has been previously shown to be a very stable reference miRNA (Peltier and Latham 2008). The RQ for each miRNA in the axon compared with the soma was calculated using the equation $2^{-\Delta \Delta \mathrm{C}_{\mathrm{T}}}$, where $\Delta \Delta \mathrm{C}_{\mathrm{T}}=\Delta \mathrm{C}_{\mathrm{T} \text {,axon }}-\Delta \mathrm{C}_{\mathrm{T} \text {,soma }}$ (for example, see Table 2). As shown in Figure $2 \mathrm{~B}$, the analyzed miRNAs were distributed between cell bodies and axons in a Gaussian fashion similar to the distribution calculated for miRNAs identified using microarray profiling. These studies further revealed a high correlation between the microarray profiling data and the results of real-time RTPCR for more than $80 \%$ of the miRNAs ( $r=0.73, P<$ $0.0001)$. Consistent with the microarray results, the average relative abundance of axonal/somal miRNA obtained by real-time RT-PCR analysis was $1.2( \pm 0.1 \mathrm{SEM})$-fold. Moreover, we were able to confirm the axonal enrichment of miR-204, miR-221, miR-15b, and miR-16 and the cell body enrichment of miR-297, miR-206, and miR-124a. However, in a few cases, inconsistencies between the microarray data and the real-time RT-PCR results were identified. For example, miR-329 showed a 2.6-fold axonal enrichment by real-time RT-PCR, but the ratio of intensities (axon/ soma) obtained by microarray was $0.48( \pm 0.04$ SEM). Reasons for these discrepancies in the data are unclear, but could derive from differences in hybridization efficiencies or variations in RNA sampling.

To confirm the axonal localization of relatively abundant miRNAs identified by both microarray and qRT-PCR analyses, we performed ISH in primary SCG neurons, using locked nucleic acid (LNA) probes for miR-16, miR221, and a scrambled miR probe as a negative control. Consistent with the microarray and real-time qPCR results, miR-16 and miR-221 were readily visualized in distal axons as punctate fluorescent ISH signals (Fig. 3A,B). In contrast, 
A

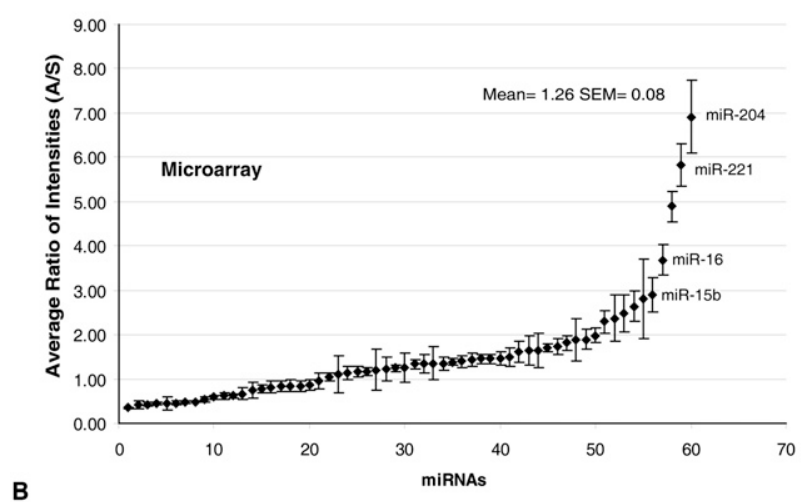

B

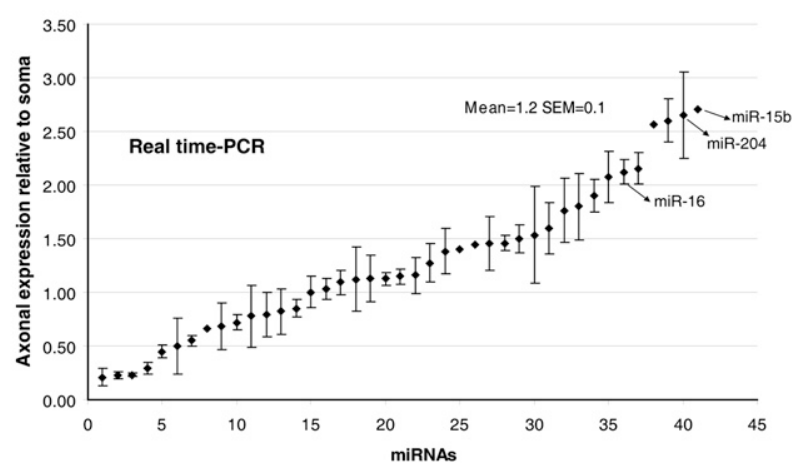

FIGURE 2. A comparison of the abundance ratios (axon/soma) of miRNAs expressed in axons as judged by microarray analysis and qRT-PCR. (A) miRNA expression in the axons assessed by microarray. The average ratios of axonal miRNA intensities relative to miRNA intensity in the soma were calculated for 60 miRNAs. Error bars represent the standard error of mean (SEM) of six replicates. $(B)$ miRNA expression in the axons assessed by real-time RT-PCR. Distribution plot shows the relative expression of axonal miRNAs compared with the soma as measured using miRNA-specific primers. Relative expression was calculated using the $2^{-\Delta \Delta \mathrm{C}_{\mathrm{T}}}$ value after normalizing the $\mathrm{C}_{\mathrm{T}}$ values in the axons and soma to the corresponding levels of U6 snRNA. The distribution can be approximated as normal by means of the Shapiro-Wilk normality test $(P=0.286)$.

no punctate fluorescent signals were observed with the scrambled miR probe (Fig. 3C).

An essential requirement for the functional role of miRNAs at post- or presynaptic endings is the targeted delivery of these noncoding RNAs along the neuronal processes. However, the mechanism of miRNA transport is entirely unknown. Several models were proposed for the shuttling of miRNAs to the synapse (Kosik 2006). The models proposed included codelivery of miRNAs with their cognate mRNA targets into neuronal endings by RNA granules, mRNA-independent delivery of mature miRNAs, as well as synaptic delivery of the precursor miRNA molecules, followed by a subsequent local processing by Dicer to the mature functional miRNA form. The latter model is supported by our previous findings of the presence of miRNA processing machinery in distal axons of sympathetic neurons (Aschrafi et al. 2008).
Many of the known miRNAs appear in clusters on a single polycistronic transcript (Lagos-Quintana et al. 2003). Although post-transcriptional regulation of miRNA expression has been demonstrated (Obernosterer et al. 2006), little is known about the regulation and processing of different miRNAs derived from the same transcript. In this study, we explored the relative distribution of miRNAs derived from 13 polycistronic transcripts. Our results indicate that the relative abundance of some of the miRNAs derived from five polycistronic gene transcripts differed significantly in the axon and cell soma (Table 3 ). This finding suggests that only a subset of polycistronically expressed miRNAs are post-transcriptionally regulated and differentially transported into the distal axons. Alternatively, the half-lives of these miRNAs might differ markedly in the two cell compartments. Whether the selective expression of polycistronically expressed miRNAs is an axon-specific phenomenon or is manifest in the dendrites is unclear, and represents an interesting question for future research.

miRNAs fine-tune the expression of their target genes in disperse locations within the cell. A particularly powerful aspect of miRNA function is the ability of individual miRNAs to coordinately regulate a multitude of genes coding for proteins with related cellular functions. Based upon this observation, we explored the possibility that miRNAs that were highly abundant or enriched in the axon had putative target genes with similar axonal functions. Using the miRNA target prediction tool TargetScan (Lewis et al. 2005), we identified putative targets for miR-204, miR-221, miR-146, miR-16 and miR-15b, miR-320, miR103, miR-541, miR-125b, miR-23a and miR-23b, miR-26a,

TABLE 2. Abundance rank ordering of axonal miRNAs as assessed by qRT-PCR analysis

\begin{tabular}{lccc}
\hline & \multicolumn{2}{c}{ Average $\mathrm{C}_{\mathrm{T}}{ }^{\mathrm{a}}$} & $\begin{array}{c}\text { Relative } \\
\text { miRNA name }\end{array}$ \\
\cline { 2 - 3 } & Axon & Soma & $\left(2^{\left.-\Delta \Delta \mathrm{C}_{\mathrm{T}}\right)^{\mathrm{b}}}\right.$ \\
\hline rno-miR-23b & $25.04 \pm 0.08$ & $20.05 \pm 0.18$ & $1.46 \pm 0.07$ \\
rno-miR-125b & $27.13 \pm 0.20$ & $21.12 \pm 0.14$ & $0.72 \pm 0.07$ \\
rno-miR-23a & $27.79 \pm 0.12$ & $22.69 \pm 0.07$ & $2.12 \pm 0.11$ \\
rno-miR-329 & $28.37 \pm 0.16$ & $24.20 \pm 0.04$ & $2.60 \pm 0.20$ \\
rno-miR-24 & $28.60 \pm 0.55$ & $21.75 \pm 0.04$ & $0.79 \pm 0.21$ \\
rno-miR-127 & $29.80 \pm 0.14$ & $23.73 \pm 0.21$ & $1.03 \pm 0.10$ \\
rno-miR-320 & $29.82 \pm 0.39$ & $24.12 \pm 0.25$ & $1.76 \pm 0.30$ \\
rno-miR-185 & $30.65 \pm 0.07$ & $23.90 \pm 0.09$ & $0.85 \pm 0.08$ \\
rno-miR-26a & $30.79 \pm 0.44$ & $25.42 \pm 0.18$ & $1.13 \pm 0.22$ \\
rno-miR-541 & $30.92 \pm 0.29$ & $24.60 \pm 0.06$ & $1.15 \pm 0.07$ \\
rno-miR-103 & $31.09 \pm 0.33$ & $24.58 \pm 0.03$ & $1.00 \pm 0.15$ \\
rno-let-7c & $31.25 \pm 0.25$ & $24.86 \pm 0.05$ & $1.09 \pm 0.11$ \\
rno-miR-221 & $31.41 \pm 0.33$ & $25.38 \pm 0.18$ & $1.41 \pm 0.02$ \\
rno-miR-382 & $31.46 \pm 0.18$ & $26.21 \pm 0.07$ & $1.90 \pm 0.15$ \\
rno-miR-16 & $31.53 \pm 0.31$ & $26.12 \pm 0.12$ & $2.16 \pm 0.15$ \\
\hline
\end{tabular}

${ }^{\mathrm{a}} \mathrm{C}_{\mathrm{T}}$ values are the average of three replicates $( \pm \mathrm{SD})$.

${ }^{b}$ Relative expression as calculated by the comparative threshold method (Schmittgen and Livak 2008), and as delineated in the Materials and Methods section. 
A

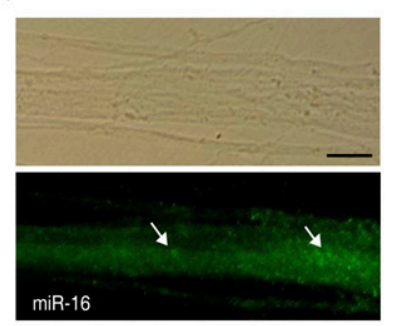

B

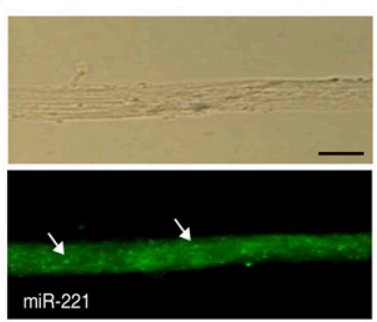

C

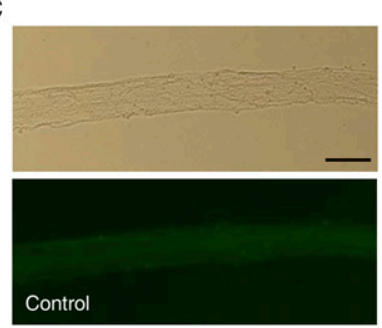

FIGURE 3. Visualization of miRNAs in distal axons by in situ hybridization (ISH). ISH was performed in primary SCG neurons at $7 \mathrm{~d}$ in vitro (DIV) using fluorescein isothiocyanate (FITC)-conjugated LNA probes for miR-16 (A), miR-221 $(B)$, and a scrambled miR probe as a negative control $(C)$. Arrows indicate the location of punctate ISH signals in distal axons for miR-16 and miR-221. Scale bars, $10 \mu \mathrm{m}$. Phase contrast images of the axon fibers are provided in the corresponding top panels.

miR-382, miR-24, and miR-185 (Table 4). Many of these target genes coded for receptors and ion channels, molecular motors, transcription and translation factors, ribosomal proteins, as well as proteins involved in vesicle recycling. All of these putative target mRNAs have been identified in the axons of invertebrates (Martin 2004; Crispino et al. 2009) and vertebrates (Willis et al. 2007; Taylor et al. 2009; Vogelaar et al. 2009). It is important to note that receptors and transmembrane proteins can be synthesized locally in axons (Spencer et al. 2000; Bi et al. 2006; Tsai et al. 2006) and that functional receptors appear to be incorporated into the axolemma via an ER- and Golgi-dependent mechanism (Merianda et al. 2009).

Although attention has been focused on miRNAs that are relatively abundant or enriched in the axon in this report (Table 1), it is likely that low abundance miRNAs might also play an important role in the regulation of local translation and axonal function. For example, the axonal localization of brain-specific miR-338 has been established by in-situ hybridization histochemistry using LNA hybridization probes, and has been shown to regulate axonal ATP synthesis and respiration in SCG neurons through modulation of COXIV mRNA levels (Aschrafi et al. 2008).

Protein translation in neurons occurs in the cell bodies or locally in the distal neuronal processes. Local protein synthesis is implicated in many aspects of neuronal development and function, such as axon guidance, dendritic elaboration, synaptic plasticity, and long-term memory formation. Although the existence of local translation in dendrites has been widely accepted, the question of whether or not translation occurs in axons has remained more controversial. Recent findings establish that proteins requisite for structural/functional maintenance of axons are synthesized locally in the axon and nerve terminal, and call attention to the intimacy of the relationship that has evolved between the distant cellular domains of the neuron and its local protein synthetic system (for review, see Kaplan et al. 2009).

In conclusion, our studies delineated the miRNAs present in the axons of sympathetic neurons, and provide an important resource for future studies on the role played by miRNAs in the regulation of intra-axonal protein synthesis.

\section{MATERIALS AND METHODS}

\section{Neuronal cell culture}

SCG were obtained from 3-d-old Harlan Sprague Dawley rats, and dissociated neurons plated in the central compartment of

TABLE 3. Overview of the ratios of intensities (axon/soma) for polycistronically expressed miRNAs ${ }^{\mathrm{a}}$

\begin{tabular}{lcc}
\hline & $\begin{array}{c}\text { Ratio } \\
\text { of intensities } \\
\text { (axon/soma) }\end{array}$ \\
miRNA & miR-433-127 cluster \\
rno-miR-433 & $1.71 \pm 0.09$ \\
rno-miR-127 & $1.44 \pm 0.15$ \\
rno-miR-136 & $0.80 \pm 0.34^{*}$ \\
rno-miR-379 & miR-379-410 cluster & \\
rno-miR-329 & & $0.45 \pm 0.15$ \\
rno-miR-487b & & $0.48 \pm 0.04$ \\
rno-miR-539 & $0.64 \pm 0.11$ \\
rno-miR-382 & $0.67 \pm 0.13$ \\
rno-miR-134 & $0.85 \pm 0.12$ \\
rno-miR-485 & $1.64 \pm 0.33^{* * *}$ \\
rno-miR-154 & $0.84 \pm 0.13$ \\
rno-miR-541 & & $0.82 \pm 0.12$ \\
rno-miR-17 & $1.49 \pm 0.21^{* * *}$ \\
rno-miR-18a & miR-17-92 cluster & $1.88 \pm 0.48$ \\
rno-miR-20a & & $0.50 \pm 0.50$ \\
rno-miR-19b & & $1.89 \pm 0.23$ \\
rno-miR-92 & & $1.26 \pm 0.32$ \\
rno-let-7c & miR-99a/let-7c/miR-125b-2 cluster \\
rno-miR-99a & & $1.45 \pm 0.09$ \\
rno-miR-125b & & $2.72 \pm 0.51^{* *}$ \\
rno-miR-25 & $1.35 \pm 0.15$ \\
rno-miR-93 & & $\pm 0.89^{*}$ \\
\hline One-106b-25 cluster & $2.15 \pm 0.33^{* *}$ \\
& & $0.85 \pm 0.18$ \\
\hline
\end{tabular}

One-way ANOVA and Tukey's HSD post-hoc test were used to calculate significant differences between the indicated miRNA(s) and the remainder of the miRNAs within the same cluster: $\left.{ }^{*}\right) P<$ $0.05 ;\left({ }^{* *}\right) P<0.01 ;\left({ }^{* * *}\right) P<0.0001$.

${ }^{\mathrm{a} D a t a}$ are the average of six replicates ( \pm SEM). 
TABLE 4. List of selected putative target genes for the abundant and/or enriched axonal miRNAs

miRNA (A/S ratio of intensity)

\begin{tabular}{|c|c|c|}
\hline \multicolumn{2}{|c|}{ Target gene } & \multirow[b]{2}{*}{ GO annotation } \\
\hline Abbreviation & Accession number & \\
\hline \multicolumn{3}{|c|}{ rno-miR-204 (A/S ratio of intensity $=6.92 \pm 0.83)$} \\
\hline \multicolumn{3}{|c|}{ Laminin receptor 1 (ribosomal protein SA) } \\
\hline LAMR $1^{\mathrm{a}, \mathrm{b}}$ & NM_017138.1 & $\begin{array}{l}\text { Laminin receptor activity } \\
\text { Cell-cell adhesion }\end{array}$ \\
\hline \multicolumn{3}{|c|}{ Discs, large homolog 5} \\
\hline DLG5 ${ }^{\mathrm{a}}$ & NM_001107247.1 & Cell-cell adherens junction \\
\hline \multicolumn{3}{|c|}{ Dynein, cytoplasmic, light chain 1} \\
\hline DNCLC1 $1^{\mathrm{a}}$ & NM_053319.2 & $\begin{array}{l}\text { Neurotransmitter metabolic process } \\
\text { Nitric oxide biosynthetic process }\end{array}$ \\
\hline \multicolumn{3}{|l|}{ Glyoxylase 1} \\
\hline $\mathrm{GLO}^{\mathrm{a}}$ & NM_207594.1 & Glutathione metabolic process \\
\hline \multicolumn{3}{|c|}{ Churchill domain containing 1} \\
\hline \multirow[t]{2}{*}{$\mathrm{CHURC} 1^{\mathrm{a}}$} & NM_001106741.2 & Positive regulation of transcription \\
\hline & rno-miR-221 (A/S r & $\pm 0.49)$ \\
\hline \multicolumn{3}{|c|}{ Tropomyosin $3, \gamma$} \\
\hline $\mathrm{TPM}^{\mathrm{a}}$ & NM_057208.2 & Actin binding \\
\hline \multicolumn{3}{|l|}{ Kinesin 2} \\
\hline $\mathrm{KNS}^{\mathrm{a}}$ & NM_001081973.1 & $\begin{array}{l}\text { Microtubule motor activity } \\
\text { Axon cargo transport }\end{array}$ \\
\hline \multicolumn{3}{|c|}{ Glycoprotein M6A } \\
\hline GPM6 $^{\mathrm{a}}$ & NM_178105.2 & Calcium channel activity \\
\hline \multicolumn{3}{|c|}{ Potassium large conductance calcium-activated channel, subfamily $m, \beta$} \\
\hline $\mathrm{KCNMB}^{\mathrm{a}}$ & NM_023960.2 & Calcium-activated potassium channel activity \\
\hline \multicolumn{3}{|c|}{ Churchill domain containing 1} \\
\hline CHURC1 $1^{\mathrm{a}}$ & NM_001106741.2 & Positive regulation of transcription \\
\hline \multicolumn{3}{|c|}{ ADP rybosilation factor 4} \\
\hline \multirow[t]{2}{*}{ ARF4 ${ }^{\mathrm{b}}$} & NM_024151.1 & $\begin{array}{l}\text { Epidermal growth factor receptor signaling } \\
\text { pathway } \\
\text { Small GTPase mediated signal transduction } \\
\text { Vesicle-mediated transport }\end{array}$ \\
\hline & rno-miR-146 (A/S r & $\pm 0.35)$ \\
\hline \multicolumn{3}{|c|}{ Ribosomal protein L30 } \\
\hline RPL30 ${ }^{a, b}$ & NM_022699.2 & $\begin{array}{l}\text { Translation } \\
\text { Structural constituent of ribosome }\end{array}$ \\
\hline \multicolumn{3}{|c|}{ Dynein, cytoplasmic, light chain $2 \mathrm{~A}$} \\
\hline DNCL2A $\mathrm{A}^{\mathrm{a}}$ & NM_131910.3 & $\begin{array}{l}\text { Motor activity } \\
\text { Retrograde axon transport }\end{array}$ \\
\hline \multicolumn{3}{|c|}{ Aldo-keto reductase family 1 , member $\mathrm{A} 1$} \\
\hline $\mathrm{AKR} 1 \mathrm{~A} 1^{\mathrm{a}, \mathrm{b}}$ & NM_031000.3 & Alcohol dehydrogenase (NADP+) activity \\
\hline \multicolumn{3}{|c|}{ ATP synthase, $\mathrm{H}+$ transporting, mitochondrial F0 complex, subunit F6 } \\
\hline ATP5J ${ }^{\mathrm{a}}$ & NM_053602.1 & $\begin{array}{l}\text { Mitochondrial proton-transporting ATP synthase } \\
\text { complex, coupling factor } \mathrm{F}(\mathrm{o})\end{array}$ \\
\hline \multicolumn{3}{|c|}{ CUG triplet repeat, RNA binding protein 2} \\
\hline $\mathrm{CUGBP}^{\mathrm{a}}$ & NM_017197.2 & $\begin{array}{l}\text { mRNA processing } \\
\text { RNA binding }\end{array}$ \\
\hline Syntaxin 7 & & \\
\hline STX7 ${ }^{\mathrm{a}}$ & NM_021869.2 & $\begin{array}{l}\text { Synaptic vesicle exocytosis } \\
\text { SNAP receptor activity }\end{array}$ \\
\hline Casein kinase & & \\
\hline $\mathrm{CSNK} 2 \mathrm{~A} 1^{\mathrm{a}}$ & NM_053824.2 & $\begin{array}{l}\text { Wnt receptor signaling pathway } \\
\text { Protein phosphatase activity }\end{array}$ \\
\hline Colony stimula & & \\
\hline CSF1R $^{b}$ & NM_001029901.1 & $\begin{array}{l}\text { Transmembrane receptor protein tyrosine kinase } \\
\text { signaling pathway }\end{array}$ \\
\hline & & Protein tyrosine kinase activity \\
\hline
\end{tabular}

(continued) 
TABLE 4. Continued

miRNA (A/S ratio of intensity)

\begin{tabular}{llc}
\hline \multicolumn{2}{c}{ Target gene } & \\
\hline Abbreviation & Accession number & GO annotation \\
\hline
\end{tabular}

Barrier to autointegration factor 1 BANF1 ${ }^{\text {b }}$

NM_053631.2 DNA binding

Ribosomal protein L32

RPL32 ${ }^{\mathrm{a}}$

rno-miR-16/15b (A/S ratio of intensity $=3.69 \pm 0.35 / 2.90 \pm 0.39)$

Tumor protein, translationally controlled 1

NM_013226.2

Translation

Structural constituent of ribosome

TPT $^{\text {a }}$

Ribosomal protein L41

RPL41 $1^{\mathrm{a}, \mathrm{b}}$

NM_053867.1

NM_139083.1

Kinesin familiy member $5 \mathrm{~A}$

KIF5A ${ }^{\text {a }} \quad$ NM_212523.1

Heterogenous nuclear ribonucleoprotein $\mathrm{A} 1$ HNRPA $^{a, b}$

Mitogen activated protein kinase 8 interacting protein

MAPK8IPa $\quad$ NM_053777.1

Glutamate receptor, ionotropic, $\mathrm{N}$-methyl D-aspartate- Like $1 \mathrm{~A}$

GRINL1A $^{\text {a }} \quad$ NM_183402.1

rno-miR-320 (A/S ratio of intensity $=2.29 \pm 0.24)$

Ribosomal protein L15

RPL15

NM 139114.3

Catenin (cadherin associated protein), $\beta$ 1, $88 \mathrm{kDa}$ CTNNB1 $1^{a, b}$

NM_053357.2

Zinc finger protein 161

ZFP161 ${ }^{\text {a }}$

NM_172325.1

Churchill domain containing 1

$\mathrm{CHURC}^{\mathrm{a}}$

NM_001106741.2

Glutamate receptor, ionotropic, $\mathrm{N}$-methyl $\mathrm{D}$-aspartate- Like $1 \mathrm{~A}$

$$
\text { GRINL1A }^{\text {a }} \quad \text { NM_183402.1 }
$$

CDK5 activator binding protein

CDK5RAP2 $^{\text {b }}$

XM_575844.2

Tubulin, $\alpha 1 \mathrm{~A}$

TUBA1 $\mathrm{A}^{\mathrm{b}}$

NM_022298.1

Peroxiredoxin 1

PRDX $1^{b}$

NM_057114.1

Enolase 1, $\alpha$

$\mathrm{ENO}^{\mathrm{b}}$

NM_012554.2

Ubiquitin carboxy-terminal hydroxylase L1

UCHL $1^{\text {b }}$

NM_017237.2
Calcium ion binding

Translation

Structural constituent of ribosome

Microtubule motor activity

mRNA transport

mRNA processing

Regulation of JNK cascade

Kinesin binding

Transcription

DNA-directed RNA polymerase activity
Translation

Structural constituent of ribosome

Regulation of transcription

Wnt receptor signaling pathway

Zinc ion binding

Protein binding

Nucleic acid binding

Positive regulation of transcription

Transcription

DNA-directed RNA polymerase activity

Neuronal Cdc2-like kinase binding

Microtubule-based movement

GTPase activity

Cell redox homeostasis

Response to oxidatve stress

Glycolysis

Phosphopyruvate hydratase activity

Ubiquitin-dependent protein

catabolic process

Ubiquitin thiolesterase activity 
TABLE 4. Continued

miRNA (A/S ratio of intensity)

\begin{tabular}{|c|c|c|}
\hline \multicolumn{2}{|c|}{ Target gene } & \multirow[b]{2}{*}{ GO annotation } \\
\hline Abbreviation & Accession number & \\
\hline \multicolumn{3}{|c|}{ rno-miR-103 (A/S ratio of intensity $=1.81 \pm 0.15)$} \\
\hline \multicolumn{3}{|c|}{ Ribosomal protein L32 } \\
\hline \multirow[t]{2}{*}{ RPL32 $2^{\mathrm{a}}$} & NM_013226.2 & Translation \\
\hline & & Structural constituent of ribosome \\
\hline \multicolumn{3}{|c|}{ Tropomyosin 3, $\gamma$} \\
\hline $\mathrm{TPM}^{\mathrm{a}}$ & NM_057208.2 & Actin binding \\
\hline \multicolumn{3}{|c|}{ Kinesin family member $5 \mathrm{~A}$} \\
\hline \multirow[t]{2}{*}{ KIF5 $A^{a}$} & NM_212523.1 & Microtubule motor activity \\
\hline & & Kinesin complex \\
\hline \multicolumn{3}{|c|}{ Mitogen activated protein kinase 8 interacting protein } \\
\hline \multirow[t]{2}{*}{ MAPK8IP ${ }^{a}$} & NM_053777.1 & Regulation of JNK cascade \\
\hline & & Kinesin binding \\
\hline \multicolumn{3}{|l|}{ Kinesin 2} \\
\hline \multirow[t]{2}{*}{$\mathrm{KNS}^{\mathrm{a}}$} & NM_001081973.1 & Microtubule motor activity \\
\hline & & Axon cargo transport \\
\hline \multicolumn{3}{|c|}{ Adenylate kinase 2} \\
\hline \multirow[t]{2}{*}{$\mathrm{AK}^{\mathrm{a}}$} & NM_030986.1 & Adenine metabolic process \\
\hline & & Adenylate kinase activity \\
\hline \multicolumn{3}{|c|}{ Glutathione peroxidase } \\
\hline \multirow[t]{2}{*}{ GPX4 ${ }^{\mathrm{a}}$} & NM_017165.2 & $\begin{array}{l}\text { Phospholipid-hydroperoxide glutathione } \\
\text { peroxidase activity }\end{array}$ \\
\hline & & Mitochondrial inner membrane \\
\hline \multicolumn{3}{|l|}{ Syntaxin 7} \\
\hline \multirow[t]{2}{*}{$\mathrm{STX} 7^{\mathrm{a}}$} & NM_021869.2 & Synaptic vesicle exocytosis \\
\hline & & SNAP receptor activity \\
\hline \multicolumn{3}{|c|}{ Golgi associated, $\gamma$ adaptin ear containing, ARF binding protein 3} \\
\hline $\mathrm{GGA}^{\mathrm{a}}$ & NM_001108304.1 & Intracellular protein transport \\
\hline Cyclin G asso & & \\
\hline $\mathrm{GAK}^{\mathrm{a}}$ & NM_031030.1 & Protein amino acid phosphorylation \\
\hline & & Protein serine/threonine kinase activity \\
\hline Phospolipase & & \\
\hline $\mathrm{PLCB} 1^{\mathrm{a}}$ & NM_001077641.1 & Lipid catabolic process \\
\hline & & Phosphoinositide phospholipase $\mathrm{C}$ activity \\
\hline & & Phosphoric diester hydrolase activity \\
\hline Cysteine-rich & & \\
\hline $\mathrm{CRIP}^{\mathrm{a}}$ & NM_022501.1 & Zinc ion binding \\
\hline & & Metal ion binding \\
\hline RAN, membe & & \\
\hline $\mathrm{RAN}^{\mathrm{a}}$ & NM_053439.1 & Microtubule cytoskeleton organization \\
\hline & & GTPase activity \\
\hline Zinc finger pr & & \\
\hline ZFP161 $1^{a, b}$ & NM_172325.1 & Zinc ion binding \\
\hline & & Protein binding \\
\hline & & Nucleic acid binding \\
\hline Churchill dom & & \\
\hline $\mathrm{CHURC}^{\mathrm{a}}$ & NM_001106741.2 & Positive regulation of transcription \\
\hline Sterol regulatc & (predicted) & \\
\hline SREBF2 ${ }^{\mathrm{a}}$ & NM_001033694.1 & Positive regulation of transcription from RNA \\
\hline & & polymerase II promoter \\
\hline & & Steriod metabolic process \\
\hline & & Response to hormone stimulus \\
\hline Nuclear facto & & \\
\hline $\mathrm{NFIB}^{\mathrm{a}}$ & NM_031566.1 & Regulation of transcription, DNA dependent \\
\hline Tubulin $\alpha$ A1 & & \\
\hline TUBA1 $A^{b}$ & NM_022298.1 & Microtubule-based movement \\
\hline & & GTPase activity \\
\hline
\end{tabular}

(continued) 
TABLE 4. Continued

miRNA (A/S ratio of intensity)

\begin{tabular}{|c|c|c|}
\hline \multicolumn{2}{|c|}{ Target gene } & \multirow[b]{2}{*}{ GO annotation } \\
\hline Abbreviation & Accession number & \\
\hline \multicolumn{3}{|l|}{ Cystatin 3} \\
\hline \multirow[t]{3}{*}{$\mathrm{CST}^{\mathrm{b}}$} & NM_012837.1 & Response to axon injury \\
\hline & & Positive regulation of DNA replication \\
\hline & & Cysteine-type endopeptidase inhibitor activity \\
\hline \multicolumn{3}{|c|}{ Ribosomal protein L41 } \\
\hline \multirow[t]{2}{*}{$\mathrm{RPL} 41^{\mathrm{b}}$} & NM_139083.1 & Translation \\
\hline & & Structural constituent of ribosome \\
\hline \multicolumn{3}{|c|}{ Calcium channel, voltage-dependent, $L$ type, $\alpha 1 \mathrm{C}$ subunit } \\
\hline \multirow[t]{2}{*}{$\mathrm{CACNA}_{1} \mathrm{C}^{\mathrm{b}}$} & NM_012517.2 & Calcium ion transport \\
\hline & & Voltage-gated calcium channel activity \\
\hline \multicolumn{3}{|c|}{ Calpain, small subunit 1} \\
\hline \multirow[t]{2}{*}{ CAPNS1 $1^{\mathrm{b}}$} & NM_017118.1 & Calcium ion binding \\
\hline & & $\begin{array}{l}\text { Calcium-dependent cysteine-type } \\
\text { endopeptidase activity }\end{array}$ \\
\hline \multicolumn{3}{|c|}{ Thymus cell surface antigen } \\
\hline \multirow[t]{2}{*}{$\mathrm{THY}^{\mathrm{b}}$} & NM_012673.1 & Negative regulation of axonogenesis \\
\hline & & $\begin{array}{l}\text { Positive regulation of peptidyl-tyrosine } \\
\text { phosphorylation }\end{array}$ \\
\hline & rno-miR-541 (A/S r & $\pm 0.21)$ \\
\hline \multicolumn{3}{|c|}{ Arginase type II } \\
\hline \multirow[t]{2}{*}{$\mathrm{ARG} 2^{\mathrm{a}}$} & NM_019168.1 & Arginine metabolic process \\
\hline & rno-miR-125b (A/S & $\pm 0.15)$ \\
\hline \multicolumn{3}{|c|}{ Golgi SNAP receptor member 1} \\
\hline \multirow[t]{3}{*}{ GOSR $1^{a}$} & NM_053584.2 & Retrograde transport, endosome to golgi \\
\hline & & ER to golgi vesicle mediated transport \\
\hline & & SNAP receptor activity \\
\hline \multicolumn{3}{|c|}{ Ubiquitin A-52 residue ribosomal protein fusion product 1} \\
\hline UBA52 $2^{a, b}$ & NM_031687.3 & Positive regulation of transcription \\
\hline \multicolumn{3}{|l|}{ Stathmin-like 3} \\
\hline \multirow[t]{2}{*}{ STMN3 $3^{a}$} & NM_024346.1 & Tubulin binding \\
\hline & & Microtubule depolymerization \\
\hline \multicolumn{3}{|c|}{$\mathrm{NADH}$ dehydrogenase (ubiquinone) flavoprotein 3-like } \\
\hline \multirow[t]{2}{*}{ NDUFV3L ${ }^{a}$} & NM_001101011.2 & Electron transport chain \\
\hline & & Mitochondrial inner membrane \\
\hline Dynein, cytop & hain 1 & \\
\hline DNCLI1 ${ }^{\mathrm{a}}$ & NM_145772.1 & ATP binding \\
\hline & & Motor activity \\
\hline Zinc finger pro & & \\
\hline ZFP161 ${ }^{a, b}$ & NM_172325.1 & Zinc ion binding \\
\hline & & Protein binding \\
\hline & & Nucleic acid binding \\
\hline Churchill dom & & \\
\hline $\mathrm{CHURC}^{\mathrm{a}}$ & NM_001106741.2 & Positive regulation of transcription \\
\hline Casein kinase & & \\
\hline $\mathrm{CSNK} 2 \mathrm{~A} 1^{\mathrm{a}}$ & NM_053824.2 & Wnt receptor signaling pathway \\
\hline & & Protein phosphatase activity \\
\hline & miR-23a,b (A/S ratio o & $2 / 1.16 \pm 0.12)$ \\
\hline Ribosomal pro & & \\
\hline RPS23 $3^{a, b}$ & NM_078617.2 & Translation \\
\hline & & Structural constituent of ribosome \\
\hline Up-regulated c & vth 5 & \\
\hline USMG5 $5^{\mathrm{a}}$ & NM_133544.1 & Integral to membrane \\
\hline & & Mitochondrion \\
\hline
\end{tabular}


TABLE 4. Continued

miRNA (A/S ratio of intensity)

\begin{tabular}{|c|c|c|}
\hline \multicolumn{2}{|c|}{ Target gene } & \multirow[b]{2}{*}{ GO annotation } \\
\hline Abbreviation & Accession number & \\
\hline \multicolumn{3}{|c|}{ Tropomyosin 3, $\gamma$} \\
\hline TPM3 $^{\mathrm{a}}$ & NM_057208.2 & Actin binding \\
\hline \multicolumn{3}{|c|}{ Neural precursor cell expressed, developmentally down-regulated gene 8} \\
\hline NEDD $8^{\mathrm{a}}$ & NM_138878.2 & $\begin{array}{l}\text { Regulation of transcription from RNA } \\
\text { polymerase II promoter }\end{array}$ \\
\hline \multicolumn{3}{|c|}{ Myristoylated alanine rich protein kinase $\mathrm{C}$ substrate } \\
\hline \multirow[t]{3}{*}{ MARCKS } & M59859.1 & Calmodulin binding \\
\hline & & Actin binding \\
\hline & & Protein kinase $\mathrm{C}$ binding \\
\hline \multicolumn{3}{|c|}{ CUG triplet repeat, RNA binding protein 2} \\
\hline \multirow[t]{2}{*}{$C_{C G B P 2^{a}}$} & NM_017197.2 & mRNA processing \\
\hline & & RNA binding \\
\hline \multicolumn{3}{|c|}{ MARCKS-like protein } \\
\hline$M L P^{a}$ & NM_057144.1 & Cellular calcium ion homeostasis \\
\hline \multicolumn{3}{|c|}{ COMM domain containing 3} \\
\hline $\mathrm{COMMD}^{\mathrm{a}}$ & NM_198732.1 & Protein binding \\
\hline \multicolumn{3}{|l|}{ Basonuclin 2} \\
\hline \multirow[t]{2}{*}{$\mathrm{BNC}^{\mathrm{a}}$} & NM_001106666.1 & DNA binding \\
\hline & & Zinc-ion binding \\
\hline \multicolumn{3}{|c|}{ Solute carrier family 25 (mitochondrial carrier; adenine nucleotide translocator), member 4} \\
\hline \multirow[t]{3}{*}{$\mathrm{SLC} 25 \mathrm{~A} 4^{\mathrm{a}}$} & NM_053515.1 & Glutamate uptake \\
\hline & & Transmembrane transport \\
\hline & & Adenine nucleotide transmembrane \\
\hline \multicolumn{3}{|c|}{ CREB binding protein } \\
\hline CREBBP $^{\mathrm{a}}$ & NM_133381.2 & Positive regulation of transcription from RNA \\
\hline & & polymerase II promoter \\
\hline \multicolumn{3}{|c|}{ Protein phosphatase 3 , catalytic subunit, $\alpha$ isoform } \\
\hline \multirow[t]{3}{*}{ PPP3CA ${ }^{a}$} & NM_017041.1 & Regulation of synaptic transmission \\
\hline & & Calcium ion transport \\
\hline & & Phosphoprotein phosphatase activity \\
\hline \multicolumn{3}{|c|}{ Zinc finger protein 161} \\
\hline \multirow[t]{3}{*}{ ZFP161 } & NM_172325.1 & Zinc ion binding \\
\hline & & Protein binding \\
\hline & & Nucleic acid binding \\
\hline \multicolumn{3}{|c|}{ Katanin p60 subunit A-like 1} \\
\hline \multirow[t]{3}{*}{ KATNAL1 ${ }^{\mathrm{a}}$} & NM_001006956.1 & Microtubule-severing \\
\hline & & ATPase activity \\
\hline & & ATP binding \\
\hline Churchill dom & & \\
\hline CHURC1 ${ }^{\mathrm{a}}$ & NM_001106741.2 & Positive regulation of transcription \\
\hline Casein kinase & & \\
\hline $\mathrm{CSNK} 2 \mathrm{~A} 1^{\mathrm{a}}$ & NM_053824.2 & Wnt receptor signaling pathway \\
\hline & & Protein phosphatase activity \\
\hline Glutamate rec & D-aspartate- Like $1 \mathrm{~A}$ & \\
\hline GRINL1A ${ }^{a}$ & NM_183402.1 & Transcription \\
\hline & & $\begin{array}{l}\text { DNA-directed RNA polymerase } \\
\text { activity }\end{array}$ \\
\hline Neurofilament & & \\
\hline $\mathrm{NEFL}^{\mathrm{b}}$ & NM_031783.1 & Anterograde axon cargo transport \\
\hline & & Retrograde axon cargo transport \\
\hline & & Axon transport of mitochondria \\
\hline Myosin regula & & \\
\hline MRLC2 ${ }^{\mathrm{b}}$ & NM_017343.2 & Motor activity \\
\hline & & Calcium ion binding \\
\hline
\end{tabular}


TABLE 4. Continued

miRNA (A/S ratio of intensity)

\begin{tabular}{lll}
\hline \multicolumn{2}{c}{ Target gene } & \\
\hline Abbreviation & Accession number & GO annotation \\
\hline & rno-miR-26a (A/S ratio of intensity $=1.24 \pm 0.06)$ &
\end{tabular}

Catenin (cadherin associated protein), $\beta 1,88 \mathrm{kDa}$
CTNNB1 $1^{a, b}$
NM_053357.2
Regulation of transcription Wnt receptor signaling pathway

Cytochrome c oxidase subunit VA $\operatorname{cox} 5 \mathrm{~A}^{\mathrm{a}}$

NM_145783.1

Cytochrome c oxidase activity

Tyrosine 3-monooxygenase/tryptophan 5-monooxygenase activation protein, $\varepsilon$ polypeptide

YWHAE $^{\text {a }} \quad$ NM_031603.1

Protein kinase $\mathrm{C}$ inhibitor activity

Microtubule associated protein 1B

MAP1 $b^{a, b} \quad$ NM_019217.1

Negative regulation of microtubule depolymerization

Transmembrane emp24-like trafficking protein 10

TMED10 ${ }^{\mathrm{b}} \quad$ NM_053467.1

Microtubule binding

\begin{tabular}{|c|c|c|}
\hline TMED10 ${ }^{\mathrm{b}}$ & NM_053467.1 & $\begin{array}{l}\text { Intracellular protein transport } \\
\text { Vesicle mediated transport }\end{array}$ \\
\hline \multicolumn{3}{|c|}{ rno-miR-382 (A/S ratio of intensity $=0.85 \pm 0.12)$} \\
\hline \multicolumn{3}{|c|}{ Ribosomal protein L32 } \\
\hline \multirow[t]{2}{*}{ RPL32 ${ }^{\mathrm{a}}$} & NM_013226.2 & Translation \\
\hline & & Structural constituent of ribosome \\
\hline \multicolumn{3}{|c|}{ Ribosomal protein S11 } \\
\hline \multirow[t]{2}{*}{ RPS1 $11^{a, b}$} & NM_031110.1 & Translation \\
\hline & & Structural constituent of ribosome \\
\hline \multicolumn{3}{|c|}{ ATP synthase, $\mathrm{H}^{+}$transporting, mitochondrial $\mathrm{F} 1$ complex, $\gamma$ polypeptide 1} \\
\hline \multirow[t]{3}{*}{ ATP5C $1^{\mathrm{a}, \mathrm{b}}$} & NM_053825.1 & Oxidative phosphorylation \\
\hline & & ATP biosynthetic process \\
\hline & & $\begin{array}{l}\text { Proton-transporting ATPase activity, } \\
\text { rotational mechanism }\end{array}$ \\
\hline \multicolumn{3}{|c|}{ Nerve growth factor receptor (TNFRS16) associated protein 1} \\
\hline NGFRAP $1^{\mathrm{a}}$ & NM_053401.1 & $\begin{array}{l}\text { Induction of apoptosis via death domain } \\
\text { receptors }\end{array}$ \\
\hline \multicolumn{3}{|c|}{ Ribosomal protein S11 } \\
\hline \multirow[t]{2}{*}{ RPS1 $11^{\mathrm{b}}$} & NM_031110.1 & Translation \\
\hline & & Structural constituent of ribosome \\
\hline \multicolumn{3}{|c|}{ Ribosomal protein L15 } \\
\hline \multirow[t]{2}{*}{ RPL15 $5^{a, b}$} & NM_139114.3 & Translation \\
\hline & & Structural constituent of ribosome \\
\hline & rno-miR-24 (A/S & $\pm 0.11)$ \\
\hline \multicolumn{3}{|c|}{ Dynein, cytoplasmic, light intermediate chain 1} \\
\hline \multirow[t]{2}{*}{ DNCLI1 ${ }^{\mathrm{a}}$} & NM_145772.1 & ATP binding \\
\hline & & Motor activity \\
\hline \multicolumn{3}{|c|}{ Pyroglutamyl-peptidase 1} \\
\hline \multirow[t]{2}{*}{ PGPEP1 ${ }^{\mathrm{a}}$} & NM_201988.2 & Proteolysis \\
\hline & & Cysteine-type peptidase activity \\
\hline \multicolumn{3}{|c|}{ Parkinson disease 7} \\
\hline PARK $7^{\mathrm{a}}$ & NM_057143.1 & Response to oxidative stress \\
\hline \multicolumn{3}{|c|}{ Translocase of inner mitochondrial membrane 13 homolog } \\
\hline \multirow[t]{2}{*}{ TIMM13 $^{\mathrm{a}}$} & NM_145781.1 & $\begin{array}{l}\text { Protein import into mitochondrial inner } \\
\text { membrane }\end{array}$ \\
\hline & & Transmembrane transport \\
\hline \multicolumn{3}{|l|}{ Matrin 3} \\
\hline \multirow[t]{2}{*}{ MATR3 $^{\mathrm{a}}$} & NM_019149.2 & RNA binding \\
\hline & & Zinc ion binding \\
\hline \multicolumn{3}{|c|}{ Churchill domain containing 1} \\
\hline CHURC1 ${ }^{\mathrm{a}}$ & NM_001106741.2 & Positive regulation of transcription \\
\hline
\end{tabular}

(continued) 
TABLE 4. Continued

miRNA (A/S ratio of intensity)

\begin{tabular}{|c|c|c|}
\hline \multicolumn{2}{|c|}{ Target gene } & \multirow[b]{2}{*}{ GO annotation } \\
\hline Abbreviation & Accession number & \\
\hline \multicolumn{3}{|c|}{ Glutamate receptor, ionotropic, $\mathrm{N}$-methyl $\mathrm{D}$-aspartate- Like 1A } \\
\hline GRINL1A ${ }^{a}$ & NM_183402.1 & $\begin{array}{l}\text { Transcription } \\
\text { DNA-directed RNA polymerase activity }\end{array}$ \\
\hline \multicolumn{3}{|c|}{ Sterol regulatory element binding factor 2 (predicted) } \\
\hline SREBF $^{\mathrm{a}}$ & NM_001033694.1 & $\begin{array}{l}\text { Specific RNA polymerase II transcription } \\
\text { factor activity } \\
\text { Steriod metabolic process } \\
\text { Response to hormone stimulus }\end{array}$ \\
\hline \multicolumn{3}{|c|}{ Neurofilament, medium polypeptide } \\
\hline NEFM $^{\mathrm{b}}$ & NM_017029.1 & $\begin{array}{l}\text { Neurofilament cytoskeleton organization } \\
\text { Axon cargo transport }\end{array}$ \\
\hline & rno-miR-185 (A/S r & $\pm 0.05)$ \\
\hline \multicolumn{3}{|c|}{ Dynein, cytoplasmic, light chain 2A } \\
\hline DNCL2A ${ }^{a}$ & NM_131910.3 & $\begin{array}{l}\text { Motor activity } \\
\text { Retrograde axon transport }\end{array}$ \\
\hline \multicolumn{3}{|c|}{ ATPase, $\mathrm{H}+$ transporting, $\mathrm{V} 1$ subunit $\mathrm{F}$} \\
\hline ATP6V1F ${ }^{\mathrm{a}}$ & NM_053884.1 & $\begin{array}{l}\text { Proton transport } \\
\text { ATP synthesis coupled protein transport } \\
\text { ATPase activity, coupled to transmembrane } \\
\text { movement of ions }\end{array}$ \\
\hline \multicolumn{3}{|c|}{ COP9 constitutive photomorphogenic homolog subunit 4} \\
\hline COPS4 ${ }^{\mathrm{a}}$ & NM_001004275.1 & Protein binding \\
\hline \multicolumn{3}{|c|}{ Cyclin G associated kinase } \\
\hline $\mathrm{GAK}^{\mathrm{a}}$ & NM_031030.1 & $\begin{array}{l}\text { Protein amino acid phosphorylation } \\
\text { Protein serine/threonine kinase activity }\end{array}$ \\
\hline \multicolumn{3}{|c|}{ Trans-2,3-enoyl-CoA reductase } \\
\hline $\mathrm{GPSN}^{\mathrm{a}}$ & NM_138549.1 & $\begin{array}{l}\text { Lipid biosynthetic process } \\
\text { Oxidoreductase activity }\end{array}$ \\
\hline \multicolumn{3}{|c|}{ Cysteine-rich protein 2} \\
\hline CRIP2 $^{\mathrm{a}}$ & NM_022501.1 & $\begin{array}{l}\text { Zinc ion binding } \\
\text { Metal ion binding }\end{array}$ \\
\hline \multicolumn{3}{|c|}{ Glutamate receptor, ionotropic, N-methyl D-aspartate- Like 1A } \\
\hline GRINL1A $^{a}$ & NM_183402.1 & $\begin{array}{l}\text { Transcription } \\
\text { DNA-directed RNA polymerase activity }\end{array}$ \\
\hline \multicolumn{3}{|l|}{ CD63 antigen } \\
\hline $\mathrm{CD}_{6} 3^{\mathrm{b}}$ & NM_017125.3 & $\begin{array}{l}\text { Positive regulation of cell adhesion } \\
\text { Positive regulation of endocytosis }\end{array}$ \\
\hline \multicolumn{3}{|c|}{ Cytochrome b-245, $\beta$ polypeptide } \\
\hline $\mathrm{CYBB}^{\mathrm{b}}$ & NM_023965.1 & $\begin{array}{l}\text { Oxidation reduction } \\
\mathrm{NAD}(\mathrm{P}) \mathrm{H} \text { oxidase activity }\end{array}$ \\
\hline $\begin{array}{l}\text { Barrier to autc } \\
\text { BANF1 }^{\text {b }}\end{array}$ & NM 053631.2 & DNA binding \\
\hline
\end{tabular}

Note: A/S indicates axon/soma.

a Presence of the mRNA in the axon previously reported by Taylor et al (2009).

beresence of the mRNA in the axon previously reported by Willis et al (2007).

Campenot compartmented culture dishes as previously described (Hillefors et al. 2007). Cells were cultured in serum-free medium containing $20 \mathrm{mM} \mathrm{KCl}$, NGF (50 ng/mL), and $20 \mathrm{U} / \mathrm{mL}$ Penicillin $/ 20 \mu \mathrm{g} / \mathrm{mL}$ Streptomycin (Hyclone) for 3-10 d prior to use, with media changes every 3-4 d. To inhibit the proliferation of nonneuronal cells, 5-fluoro-2'-deoxyuridine (50 nM) was added to the culture medium $24 \mathrm{~h}$ after plating and maintained throughout the culture period. The side compartments, which contained the distal axons used in these experiments, contained no neuronal soma or non-neuronal cells, as judged by phasecontrast microscopy, as well as ethidium bromide and acridine orange staining.

\section{Western blot analysis}

Distal axons in the side compartments of Campenot chambers or soma and proximal axons in the central compartment were

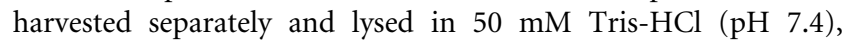


$150 \mathrm{mM} \mathrm{NaCl}, 1 \mathrm{mM}$ EDTA, 1\% NP-40, and Complete protease inhibitor cocktail (Roche). Protein concentration was assessed using the Micro BCA Protein Assay Kit (Pierce). For SDS-PAGE, equal amounts $(2-5 \mu \mathrm{g})$ of each lysate were boiled in NuPage sample buffer (Invitrogen) and resolved on $4 \%-12 \%$ linear gradient gels. Proteins were transferred to PVDF membranes, probed with monoclonal antibodies to $\beta$-actin, Tau, and MAP2 (Sigma), and developed using the ECL Advance Western Blotting Detection Kit (GE Health Care).

\section{In situ hybridization}

Visualization of miR-16 and miR-221 in the axons of SCG neurons was accomplished by in situ hybridization using fluorescein isothiocyanate (FITC)-conjugated LNA probes $(25 \mathrm{nM}$, Exiqon). A scrambled miR probe was employed as a negative control. We followed the protocol described in Aschrafi et al. (2010), with the following modifications. After fixation, the neurons were dehydrated and rehydrated by sequential addition of 70\%, 90\%, $100 \%, 90 \%$, and $70 \%$ ethanol solutions, and washed three times in PBS. After hybridization, the neurons were washed twice in $2 \times$ SSC and twice in $0.2 \times \mathrm{SSC}$ at $60^{\circ} \mathrm{C}$, for $30 \mathrm{~min}$ each. The signal intensity of the FITC probe was amplified with the Alexa Fluor 488 Signal Amplification Kit (Molecular Probes).

\section{RNA isolation and miRNA microarray analyses}

Total RNA was isolated from the axons or soma of SCG neurons using RiboZol RNA extraction reagent (Amresco) according to the manufacturer's protocol. The concentration and purity of the RNA were assessed using a UV spectrophotometer. Total RNA samples, isolated from the central and side compartments of the Campenot chambers, were analyzed using the NCode MultiSpecies miRNA microarray kit (Invitrogen). MicroRNA populations were polyadenylated and subsequently ligated to labeled DNA polymers using the 6X Alexa Fluor 3 (A3) or 6X Alexa Fluor 5 (A5) Rapid Ligation Mix. The two differentially labeled reactions were combined into one tube and then loaded onto NCode Multi-Species miRNA Microarray V2. The arrays were mounted with the Maui Mixer SL and hybridized overnight (16$20 \mathrm{~h}$ ) at $52^{\circ} \mathrm{C}$ with constant mixing. The arrays were washed and scanned using a GenePix 4000B microarray scanner (Molecular Devices). The scanned array images were then annotated and analyzed using the GenePix software. The annotated data were normalized using a Latin Squares algorithm by the NCode Profiler data analysis software. A dye swap analysis was performed on the data to identify differential markers. The array data were checked to ensure the median backgrounds were below 75 relative fluorescent units (RFU). Median local backgrounds were subtracted from the median spot intensities to generate background-corrected median intensities for all spots.

\section{Quantitative RT-PCR}

For optimized detection and quantification of miRNAs, cDNA was synthesized from total RNA using the NCode miRNA First Strand cDNA synthesis kit (Invitrogen) according to the manufacturer's protocol. Using first-strand cDNA as a template, triplicate qPCR reactions were performed for each miRNA using miRNA-specific forward primers and the NCode Universal qPCR reverse primer. The forward primers for $\mathrm{qPCR}$ analyses for each
miRNA were designed using the entire mature miRNA sequence. Minus template and minus forward primer controls were included to ensure lack of signal in the assay background. All $\mathrm{C}_{\mathrm{T}}$ values used for analyses were averaged from three to six replicates and those with high standard deviation $(>1)$ were not included in the analyses. Melting curve analysis was performed to test for the specificity and quality of the qPCR amplifications. Relative expression was calculated using the comparative $\mathrm{C}_{\mathrm{T}}$ method and normalized to the expression of U6 snRNA and miR-103. Using miR-221 as an example, the relative expression (RQ) was calculated as follows:

$$
\begin{aligned}
\Delta \Delta \mathrm{C}_{\mathrm{T}}= & \Delta \mathrm{C}_{\mathrm{T}, \text { axon }}-\Delta \mathrm{C}_{\mathrm{T}, \text { soma }}=\left[\mathrm{C}_{\mathrm{T}, \mathrm{miR}-221}-\mathrm{C}_{\mathrm{T}, \mathrm{U} 6}\right]_{\mathrm{axon}} \\
& -\left[\mathrm{C}_{\mathrm{T}, \mathrm{miR}-221}-\mathrm{C}_{\mathrm{T}, \mathrm{U} 6}\right]_{\mathrm{soma}}=[31.41-29.45] \\
& -[25.39-23.97]=1.92-2.41=-0.49
\end{aligned}
$$

where relative expression (or RQ) $=2^{-\Delta \Delta C}{ }_{T}=2^{-(-0.49)}=1.41$.

RT-PCR methodology was also used to assess the purity of the axonal RNA preparations. In these experiments, total RNA was reverse transcribed using oligo (dT) primers and SuperScript FirstStrand Synthesis Kit (Invitrogen). Amplification was accomplished using gene-specific primers as previously described (Gioio et al. 2001). PCR reactions for synaptic vesicle associated proteins and GFAP were fractionated by electrophoresis on $2.5 \%$ agarose gels, and amplicons were visualized by ethidium bromide staining. PCR reactions without reverse transcriptase yielded no amplification products.

\section{Statistical analysis}

Student's $t$-test was used to determine significant differences between two groups. One-way ANOVA and Tukey's HSD post-hoc test were used to analyze significant differences among multiple groups; $P<0.05$ was considered significant.

\section{SUPPLEMENTAL MATERIAL}

Supplemental material can be found at http://www.rnajournal.org.

\section{ACKNOWLEDGMENTS}

This work was supported by the Division of Intramural Research Programs of the National Institute of Mental Health. We thank Dr. Lauren Taylor (Invitrogen) for assistance with the miRNA microarray studies and Dr. Marie Mameza (University of Maryland School of Medicine) for her assistance in the RT-PCR analyses of axonal and somal RNA preparations. We also thank Dr. Amar N. Kar (NIMH) for his assistance in the bioinformatic analysis of miRNA target genes.

Received July 17, 2009; accepted May 17, 2010.

\section{REFERENCES}

Aldrich BT, Frakes EP, Kasuya J, Hammonda DL, Kitamoto T. 2009. Changes in expression of sensory organ-specific microRNAs in rat dorsal root ganglia in association with mechanical hypersensitivity induced by spinal nerve ligation. Neuroscience 164: 711-723.

Ambros V, Lee RC. 2004. Identification of microRNAs and other tiny noncoding RNAs by cDNA cloning. Methods Mol Biol 265: 131-158.

Aschrafi A, Schwechter AD, Mameza MG, Natera-Naranjo O, Gioio AE, Kaplan BB. 2008. MicroRNA-338 regulates local cytochrome 
c oxidase IV mRNA levels and oxidative phosphorylation in the axons of sympathetic neurons. J Neurosci 28: 12581-12590.

Aschrafi A, Natera-Naranjo O, Gioio AE, Kaplan BB. 2010. Regulation of axonal trafficking of cytochrome $c$ oxidase IV mRNA. Mol Cell Neurosci 43: 422-430.

Bassell GJ, Warren ST. 2008. Fragile X syndrome: Loss of local mRNA regulation alters synaptic development and function. Neuron 60: 201-214.

Bi J, Tsai NP, Lin YP, Loh HH, Wei LN. 2006. Axonal mRNA transport and localized translational regulation of $\kappa$-opioid receptor in primary neurons of dorsal root ganglia. Proc Natl Acad Sci 103: 19919-19924.

Costa-Mattioli M, Sossin WS, Klann E, Sonenberg N. 2009. Translational control of long-lasting synaptic plasticity and memory. Neuron 61: 10-26.

Crispino M, Cefaliello C, Kaplan B, Giuditta A. 2009. Protein synthesis in nerve terminals and the glia-neuron unit. In Cell biology of the axon (ed. E Koenig), pp.246-267. Springer, Berlin, Germany.

Filipowicz W, Bhattacharyya SN, Sonenberg N. 2008. Mechanisms of post-transcriptional regulation by microRNAs: Are the answers in sight? Nat Rev Genet 9: 102-114.

Gioio AE, Eyman M, Zhang H, Lavina ZS, Giuditta A, Kaplan BB. 2001. Local synthesis of nuclear-encoded mitochondrial proteins in the presynaptic nerve terminal. J Neurosci Res 64: 447-453.

Hébert SS, Horré K, Nicolaï L, Bergmans B, Papadopoulou AS, Delacourte A, De Strooper B. 2009. MicroRNA regulation of Alzheimer's amyloid precursor protein expression. Neurobiol Dis 33: $422-428$.

Hillefors M, Gioio AE, Mameza MG, Kaplan BB. 2007. Axon viability and mitochondrial function are dependent on local protein synthesis in sympathetic neurons. Cell Mol Neurobiol 27: 701-716.

Huang F, Chotiner JK, Steward O. 2005. The mRNA for elongation factor $1 \alpha$ is localized in dendrites and translated in response to treatments that induce long-term depression. J Neurosci 25: 71997209.

Hunsberger JG, Austin DR, Chen G, Manji HK. 2009. MicroRNAs in mental health: From biological underpinnings to potential therapies. Neuromolecular Med 11: 173-182.

Kaplan BB, Gioio AE, Hillefors M, Aschrafi A. 2009. Axonal protein synthesis and the regulation of local mitochondrial function. In Cell biology of the axon (ed. E Koenig), pp.225-242. Springer, Berlin, Germany.

Kim VN. 2005. MicroRNA biogenesis: Coordinated cropping and dicing. Nat Rev Mol Cell Biol 6: 376-385.

Klann E, Antion MD, Banko JL, Hou L. 2004. Synaptic plasticity and translation initiation. Learn Mem 11: 365-372.

Kosik KS. 2006. The neuronal microRNA system. Nat Rev Neurosci 7: 911-920.

Kye MJ, Liu T, Levy SF, Xu NL, Groves BB, Bonneau R, Lao K, Kosik KS. 2007. Somatodendritic microRNAs identified by laser capture and multiplex RT-PCR. RNA 13: 1224-1234.

Lagos-Quintana M, Rauhut R, Meyer J, Borkhardt A, Tuschl T. 2003. New microRNAs from mouse and human. RNA 9: 175-179.

Lewis BP, Burge CB, Bartel DP. 2005. Conserved seed pairing, often flanked by adenosines, indicates that thousands of human genes are microRNA targets. Cell 120: 15-20.

Li Y, Park JS, Deng JH, Bai Y. 2006. Cytochrome c oxidase subunit IV is essential for assembly and respiratory function of the enzyme complex. J Bioenerg Biomembr 38: 283-291.
Lugli G, Torvik VI, Larson J, Smalheiser NR. 2008. Expression of microRNAs and their precursors in synaptic fractions of adult mouse forebrain. J Neurochem 106: 650-661.

Martin KC. 2004. Local protein synthesis during axon guidance and synaptic plasticity. Curr Opin Neurobiol 14: 305-310.

Merianda TT, Lin AC, Lam JS, Vuppalanchi D, Willis DE, Karin N, Holt CE, Twiss JL. 2009. A functional equivalent of endoplasmic reticulum and Golgi in axons for secretion of locally synthesized proteins. Mol Cell Neurosci 40: 128-142.

Niwa R, Slack FJ. 2007. The evolution of animal microRNA function. Curr Opin Genet Dev 17: 145-150.

Obernosterer G, Leuschner PJ, Alenius M, Martinez J. 2006. Posttranscriptional regulation of microRNA expression. RNA 12: 1161-1167.

Peltier HJ, Latham GJ. 2008. Normalization of microRNA expression levels in quantitative RT-PCR assays: Identification of suitable reference RNA targets in normal and cancerous human solid tissues. RNA 14: 844-852.

Saba R, Goodman CD, Huzarewich RL, Robertson C, Booth SA. 2008. A miRNA signature of prion induced neurodegeneration. PLoS ONE 3: e3652. doi: 10.1371/journal.pone.0003652.

Schmittgen TD, Livak KJ. 2008. Analyzing real-time PCR data by the comparative $\mathrm{C}_{\mathrm{T}}$ method. Nat Protoc 3: 1101-1108.

Schmittgen TD, Lee EJ, Jiang J, Sarkar A, Yang L, Elton TS, Chen C. 2008. Real-time PCR quantification of precursor and mature microRNA. Methods 44: 31-38.

Schratt G. 2009a. Fine-tuning neural gene expression with microRNAs. Curr Opin Neurobiol 19: 213-219.

Schratt G. 2009b. MicroRNAs at the synapse. Nat Rev Neurosci 10: 842-849.

Siegel G, Obernosterer G, Fiore R, Oehmen M, Bicker S, Christensen M, Khudayberdiev S, Leuschner PF, Busch CJ, Kane C, et al. 2009. A functional screen implicates microRNA-138-dependent regulation of the depalmitoylation enzyme APT1 in dendritic spine morphogenesis. Nat Cell Biol 11: 705-716.

Smart F, Aschrafi A, Atkins A, Owens GC, Pilotte J, Cunningham BA, Vanderklish PW. 2007. Two isoforms of the cold-inducible mRNA-binding protein RBM3 localize to dendrites and promote translation. J Neurochem 101: 1367-1379.

Spencer GE, Syed NI, van Kesteren E, Lukowiak K, Geraerts WP, van Minnen J. 2000. Synthesis and functional integration of a neurotransmitter receptor in isolated invertebrate axons. J Neurobiol 44: $72-81$.

Taylor AM, Berchtold NC, Perreau VM, Tu CH, Li JN, Cotman CW. 2009. Axonal mRNA in uninjured and regenerating cortical mammalian axons. J Neurosci 29: 4697-4707.

Tsai NP, Bi J, Loh HH, Wei LN. 2006. Netrin-1 signaling regulates de novo protein synthesis of $\kappa$ opioid receptor by facilitating polysomal partition of its mRNA. J Neurosci 26: 9743-9749.

van Rooij E, Olson EN. 2007. microRNAs put their signatures on the heart. Physiol Genomics 31: 365-366.

Vogelaar CF, Gervasi NM, Gumy LF, Story DJ, Raha-Chowdhury R, Leung KM, Holt CE, Fawcett JW. 2009. Axonal mRNAs: Characterization and role in the growth and regeneration of dorsal root ganglion axons and growth cones. Mol Cell Neurosci 42: $102-115$.

Willis DE, van Niekerk EA, Sasaki Y, Mesngon M, Merianda TT, Williams GG, Kendall M, Smith DS, Bassell GJ, Twiss JL. 2007. Extracellular stimuli specifically regulate localized levels of individual neuronal mRNAs. J Cell Biol 178: 965-980. 

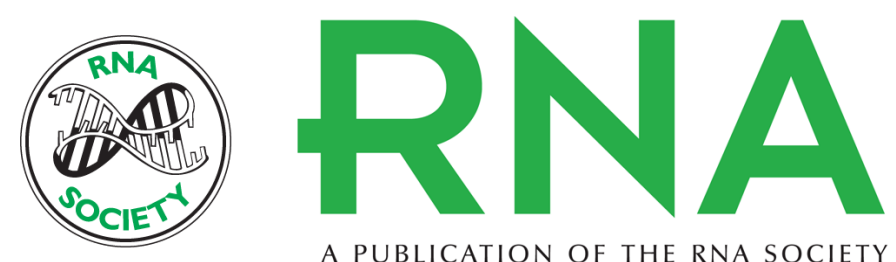

A PUBLICATION OF THE RNA SOCIETY

\section{Identification and quantitative analyses of microRNAs located in the distal axons of sympathetic neurons}

Orlangie Natera-Naranjo, Armaz Aschrafi, Anthony E. Gioio, et al.

RNA 2010 16: 1516-1529 originally published online June 28, 2010

Access the most recent version at doi:10.1261/rna.1833310

\section{Supplemental http://rnajournal.cshlp.org/content/suppl/2010/06/14/rna.1833310.DC1 \\ Material}

References This article cites 39 articles, 11 of which can be accessed free at: http://rnajournal.cshlp.org/content/16/8/1516.full.html\#ref-list-1

\section{License}

Email Alerting Receive free email alerts when new articles cite this article - sign up in the box at the Service top right corner of the article or click here. 